\title{
Missionary Hubris in Colonial Algeria? Founding and Governing Christian Arab Villages 1868-1930
}

\author{
Bertrand Taithe
}

The historiography of missionary work in the French empire often concentrates on the sub-saharan African empire, the pacific islands, or Madagascar. In all these contexts the collusion of state and Catholic Church in resisting Protestant and non-French incursions can be demonstrated over the long run even if these relations were not without their difficulties at times. ${ }^{1}$ In contrast, historians have long identified the misgivings of French military ${ }^{2}$ leaders concerned with the risks that overt proselytizing might represent in established Muslim societies. This cautious attitude characterized the fine balancing act undertaken by the French state in Algeria. ${ }^{3}$ The colony, which was simultaneously one of the most difficult spaces to control over the period 18301871 and the one territory overseas destined to become part of France, was a prime example of the political tensions arising from missionary activities. From 1868 until 1939, French missionaries in Algeria played a significant role in challenging the Second Empire and the Third Republic. In turn undermining the Royaume Arabe separate development ideology of Napoleon III's regime ${ }^{4}$ and challenging the increasingly racialized segregation policies of mostly anti-

1 See Sarah E. Curtis, Civilizing Habits: Women Missionaries and the Revival of French Empire (Oxford: Oxford University Press, 2010); James-Patrick Daughton and Owen White, In God's Empire: French Missionaries and the Modern World (Oxford: Oxford University Press, 2011); for a good discussion of religious conflicts in the empire, J.P. Daughton, An Empire Divided: Religion, Republicanism and the Making of French Colonialism, 1880-1914 (Oxford: Oxford University Press, 2006); Robert Aldrich, The French Presence in the South Pacific, 1842-1940 (London: Macmillan, 1990). There were of course French protestant missionaries active in the French and British empires. See Jean-François Zom, Le Grand Siècle d'une mission protestante: La mission de Paris de 1822 à 1914, 2nd ed. (Paris: Karthala, 2012).

2 This is well documented for the French Sudan. See Joseph-Roger de Benoist, Église et Pouvoir Colonial au Soudan Français (Paris: Karthala, 1987).

3 Oissila Saaidia, Algérie colonial. Musulmans et chrétiens: le contrôle de l'Etat (1830-1914) (Paris: CNRS, 2015); Dominique Urvoy, "Les conversions au catholicisme en Algérie," Outre-Terre 2015/4, no. 45 (2015): 249-255.

4 Annie Rey-Goldzeiguer, Le Royaume arabe, la politique algérienne de Napoléon III (Algiers: Société Nationale d'Édition et de Diffusion, 1977); Georges Spillmann, Napoléon III et le roy-

(C) BERTRAND TAITHE, 2020 | DOI:10.1163/9789004434530_008

This is an open access chapter distributed under the terms of the CC BY-NC 4.o license $r$ rand Taithe - 9789004434530 
clerical republicans, missionaries sought to present an alternative vision of what Algeria might become should it be converted to Catholicism. In many ways these missionary aspirations matched the colonial humanitarianism that Alan Lester described in relation to the British empire's treatment of aboriginal people in the antipodeans. In this mode of governmentality, which was developed earlier in the 19th century, the treatment of native Australians offered the possibility of protection at the expense of their genuine human rights or the more predatory economic rights of the settlers. Lester argues that this mode of colonial governmentality attempted to find a humanitarian way which would resist revolutionary individualism and some of the most egregious consequences of capitalism. ${ }^{5}$ Missionaries in North Africa sometimes made themselves the comparison between Arabs and aborigines, and they too sought to build a mode of governance which might offer a path to social and cultural conversion to a profoundly anti-revolutionary way of being French.

The primary spokesperson of this ambitious dream was Mgr Lavigerie who, together with his missionary society, the White Fathers, sought to exploit the crises of the late 186os to articulate afresh their vision of a new society. ${ }^{6}$ Though successful in setting up some model villages and modest Christian communities under their paternalist governance, the Republican regime proved much more effective in containing the political threat Catholic Arabs might represent. This chapter will show how, over a long period, a hubristic dream became reduced to a political and social anomaly in the increasingly racialized politics of Colonial Algeria.

The paradox of missionary presence in French colonial Algeria could not be better illustrated than through the extraordinary homage that the republicans offered the Archbishop of Carthage Charles Lavigerie in 1892. Arguably the most significant prelate in the French empire by the time of his death, Charles Martial Allemand Lavigerie, Cardinal since 1882, Archbishop of Algiers since 1867, had only two years before his death signified the potential acceptance of the Republic by the Catholic Church in a famous address to the French navy. ${ }^{7}$ His funerals involved the military and civilian authorities united in honouring

aume arabe d'Algérie, Paris, Travaux et mémoires de l'Académie des sciences d'outre-mer, nouvelle série 3 (Paris: Académie des Sciences d'Outre-mer, 1975).

5 Alan Lester and Fae Dussart, Colonization and the Origins of Humanitarian Governance: Protecting Aborigines across the Nineteenth Century British Empire (Cambridge: Cambridge University Press, 2014).

6 For a history of the White Fathers see Jean-Claude Ceillier, Histoire des missionnaires d'Afrique (Pères Blancs), de la fondation par Mgr Lavigerie à la mort du fondateur (1868-1892) (Paris: Karthala, 2008).

7 Xavier de Montclos, Lavigerie le Saint-Siège et l'Église: De l'avènement de Pie IX à l'avènement 
him. His remains were the object of processions and his coffin was taken by the French Navy to his resting place in Tunis.

What were they celebrating? The man who had ruled with an iron fist the Catholic Church in Algiers, Constantine, and Tunisia? The man who had brought about, through a single toast at a dinner party, the promise of a ralliement of the Catholic church to the republic? The opponent of the military regime and of the Royaume Arabe who did not fear from engaging with republicans in order to challenge MacMahon's restrictions on commercial and agricultural developments? The international crusader against African slavery and the Zanzibarian slave trade? The man of the Alliance Française? Or the missionary innovator whose Société des Missionnaires d'Afrique now made inroads across the continent. Whatever it was Lavigerie incarnated it was controversial. One point detractors and admirers could agree on: Lavigerie had transformed the Catholic Church in North Africa and its fortunes. Though extremely diverse his career followed one significant thread, the desire to force French colonial authorities to grant full apostolic freedom in Muslim territories in order for the Church to renew its pastoral authority. ${ }^{8}$

Throughout his life and since his arrival in Algeria in 1868, in the midst of a famine, ${ }^{9}$ Lavigerie had challenged the notion that Muslim societies could not be converted or that ardent missionary activity should be circumscribed to existing Christian communities. ${ }^{10}$ Inheriting a near bankrupt institution, ${ }^{11}$ Lavigerie demonstrated a most unusual businesslike approach to restoring the fortunes of the Catholic Church, sometimes at the expense of his competitors including bishops of neighbouring dioceses. ${ }^{12}$ As a result of his many ventures and international fundraising - the Algerian church experienced in 30 years a massive increase of its income, a flourishing of its business interests,

de Léon XIII, 1846-1878 (Paris: de Boccard, 1965); François Renault, Le Cardinal Lavigerie (Paris: Fayard, 1992).

8 Much of the historiography of Algeria has tended to focus on this specific question e.g. Charles André Julien, Histoire de l'Algérie Contemporaine vol. 1 (Paris: Presses Universitaires de France, 1986), 441-443; Marcel Émerit, "Le problème de la conversion des musulmans d'Algérie sous le Second Empire: Le conflit entre Mac-Mahon et Lavigerie," Revue Historique 223, no. 1 (1960): 63-84.

9 Djilali Sari, Le désastre démographique (Algiers: Société Nouvelle d'Édition et de Diffusion, 1982).

10 Abbé Bellarmin-Vincent Burzet, Histoire des désastres de l'Algérie, 1866-1867-1868: Sauterelles, tremblement de terre, choléra, famine (Algiers: Garaudel, 1869).

11 Archives Générales des Missionnaires d'Afrique (AGMAfr), A16, abbé Hodard, Introduction aux ouvres de Mgr Pavy (Algiers, nd).

12 This is well documented for Mgr de Las Cases, see Henri Barthès, Monseigneur de las Cases, évêque de Constantine (Montpellier: Presses Universitaires de Paul Valéry, 1980). 
the development of networks of charities, and a much greater density of religious activities providing dispensaries, schools, asylums for the elderly and orphans.

In this he was not alone since many bishops also innovated in making the Catholic wealthy once again but they usually benefited from the support of wealthy donors-in short supply in Algeria. Lavigerie thus had to internationalize his cause and make it emblematic of a militant Church going global. The Catholic Church in North Africa before 1868 was meant to service the spiritual needs of a thin strip of parishes populated by the very diverse "European" population of the colony. When it sought to expand its remit to the wider context, it was relentlessly opposed by military officers and in particular the notorious bureaux arabes, the embedded information offices which monitored the tribes of hinterland Algeria. ${ }^{13}$

Missionaries had been severely curtailed in their activities even though they perceived some of Algeria to be so-called "crypto Christians". The Kabyles, that is the Tamazight (Berber) speakers of Algeria, presented village communities with local civic organizations which led French administrators of the 186os to imagine them as most receptive to French civilization if not outright Christianity. ${ }^{14}$ As Patricial Lorcin and Alain Mahé have shown there was considerable ethnographic interest and depth in the making of a Kabyle myth which encouraged some priests to attempt apostolic missions in the mountains of Algeria. ${ }^{15}$ These initiatives were limited before the arrival of Lavigerie and they only grew in a very modest fashion after his installation in Algiers. Soon the reality of facing complex and resilient societies which were in 1871 one of the hotbeds of resistance to French occupation and a site of Djihad undermined any grand expansion plan.

13 Abdelmajid Hannoum, "Colonialism and knowledge in Algeria: The archives of the Arab bureau," History and Anthropology vol. 12, no. 4 (2001): 345-379; Jacques Frémeaux, Les bureaux arabes dans l'Algérie de la conquête (Paris: Denoël, 1993).

14 Adolphe Hanoteau and Aristide Letourneux, La Kabylie et les coutumes Kabyles (Paris: Imprimerie nationale, $1872-1873)$. On the religious question Hanoteau and Letourneux were very sceptical even if they stressed the parallels between village life in Kabylie and France. See Karima Dirèche, Chrétiens de Kabylie (1873-1954). Une action missionnaire dans l'Algérie coloniale (Saint Denis: Bouchène, 2004); Karima Dirèche, "Les écoles catholiques dans la Kabylie du XIX ${ }^{\mathrm{e}}$ siècle," Cahiers de la Méditerranée, 75 (2007): 17-27, available via http://journals.openedition.org/cdlm/3333.

15 Alain Mahé, Histoire de la Grande Kabylie, anthropologie historique du lien social dans les communautés villageoises (Saint Denis: Bouchène, 2001), 181-19o; Patricia M.E. Lorcin, Kabyles, arabes, français: Identités colonials (Limoges: Presses Universitaires de Limoges, 2005). 
Lavigerie nevertheless proved a great innovator and a remarkably opportunistic entrepreneur. He brought to life a range of initiatives, often without resourcing them outright and sought in the wider Catholic world support for his campaigns. His most significant success was the Société des Missionnaires d'Afrique. In the 188 os and 189 os, the society expanded mostly in sub-Saharan Africa in competition with other religious orders (such as the Spiritans). Until his death, Lavigerie ruled the missionary organization with an iron fist which contrasted with his more difficult relations with the parish clergymen of his diocese. As a missionary army, Lavigerie's society proved very resilient to the very strong anticlerical pressures exercised in Algeria. In order to avoid too much financial scrutiny, Lavigerie did not hesitate to displace his offices and training college to Malta and Rome. While the Catholic Church remained in tacit and sullen opposition to the French republic from 1870 until 189o, Lavigerie's missionaries were working closely with some of the colonial authorities despite concerns among a significant portion of the settlers. The White Fathers became the embodiment of an alliance of militarism and missionary work in the colonial landscape (with two separate examples of attempted private militia in Congo and in the Sahara) and of high colonial missionary work. ${ }^{16}$ To the point that when Catholic missionaries experienced their about-turn and considerable revision of their position in relation to the colonial regime in the 1920s, the White Fathers stood as the butt of many of criticism of what missions ought not to be.

In many ways Lavigerie had succeeded most where he was not-in Sub Saharan Africa, in France where his society was mocked but also admired and worldwide where it recruited. Arguably Algeria and the complex colonial society of the colony resisted the charisma and brutal efficiency of the cardinal. As many historians of missions in North Africa and in the Middle East have shown the task of missionary work in Dar al Islam proved difficult and contradictory. There his aspirations remained at their most hubristic, impossibly grand considering his resources and intractable in their politics to a fast changing colonial society and state.

16 Bertrand Taithe, "Missionary Militarism? The Armed Brothers of the Sahara and Leopold Joubert in the Congo," in God's Empire: French Missionaries and the Modern World, eds. James-Patrick Daughton and Owen White (Oxford: Oxford University Press, 2011), 12915 o. 
I have written elsewhere on the scale of Catholic response to the famine that affected Algeria between 1865 and $1868 .{ }^{17}$ The concept of famine itself was a hotly contested notion which remains controversial today and which Lavigerie single handedly promoted worldwide to describe the immense poverty of eastern Algeria. Throughout the events of 1868 Lavigerie challenged the French military authorities to respond to the crisis by dismantling their own regulatory framework and admitting the bankruptcy of the policies underpinning the Royaume Arabe promoted by Napoleon III. ${ }^{18}$ In particular the crisis revealed, according to Lavigerie, the fundamental lack of compassion in Muslim society. It significantly opened up the doors to more interventionist responses. In this context Lavigerie identified three groups worthy of Christian charity which were according to him either neglected or exploited in Muslim society: the elderly, divorced women, and orphans. He correspondingly opened up institutions for all three groups.

While the abandoned women represented an iconic group of gender differences between Christian and Muslim society, they were neither a large group nor one with any potential for growth. The same applied to the abandoned elderly who tended to be a small group of alienated individuals. Orphans in contrast represented a very significant constituency, a cultural blank slate with potential for further development and exemplary uses. Catholic orphanages in France had long been one of the traditional roles of the Church. These institutions, part-prison part-school, played their containment role with the support of municipal authorities and catered at a fairly basic level for the needs of a large disenfranchised community. But there was one significant innovation in the French orphanages with the the setting up in 1866 of the Apprentis d'Auteuil institution by Abbot Roussel. ${ }^{19}$ Aimed at street orphans and impoverished abandoned children, the apprentis d'auteuil intended to train and discipline children into practical skills and in basic education in order to reChristianize the working class. Orphans/apprentices would become beacons of Catholic virtue among the poor.

17 Bertrand Taithe, “Algerian Orphans and Colonial Christianity in Algeria 1866-1939," French History 20, no. 3 (2006): 240-259.

18 Léon Hugonnet, La Crise algérienne et la démocratie (Paris: Chevalier, 1868).

19 On apprentices and different modes of adoption see Yves Denéchère, "Histoires croisées des orphelins et de l'adoption," in Invisibles orphelins, ed. Magali Molinié (Paris: Autrement, 2011), available via https://halshs.archives-ouvertes.fr/halshs-o1o9159o. 
The upheaval of 1868 provided the opportunity for the Missionaires d'Afrique to gather a large cohort. Though decimated by an epidemic, some 806 children were declared orphans by the religious authorities of Algeria and became a formidable burden to shoulder. ${ }^{20}$ The scale of the rescue could only be justified on humanitarian ground on the one hand, and by a broader sociopolitical aim on the other. Lavigerie had been involved in 1860 in supporting the écoles chrétiennes au proche orient. He had a strong interest in setting up missionary work as a pedagogical enterprise. Fundamentally Lavigerie felt that the French colonial administrators and the wider settler population needed to understand that Arab Christians were not only possible but necessary for the moral redemption of the entire colony and the Arab world at large. Though many "orphans" turned out to be no such thing in the legal definition of the term, Lavigerie associated "abandonment" to orphaning and successfully resisted any prolonged attempt by Arab families to regain control of the boys and girls the Church catered for. There were voices in the Arab community challenging the diktat and the circumstances of the adoption and on April 22, 1874 the conseil general of Algiers issued a report in response to Algerian demands that the orphans be transferred to the authority of the prefect of Algiers:

It is not an ordinary situation that had made the ecclesiastical authorities the arbiter of the fate of famine orphans succoured by the voluntary gifts of Christian folks, this situation is the product of events and it seems difficult to modify it ... Mgr Lavigerie finds himself placed in the position of an adoptive father; there is established between the protector and the protected a kind of contract. ${ }^{21}$

Paternalism as governance was thus set in place through this "adoption". Rather than a metaphorical use of the concept of paternalism-a recurrent trope in any analysis of humanitarian or development practices-one here encounters a specific legal reality and a private mode of governing over the lives of hundreds of individuals. ${ }^{22}$ Over a period of twenty years this exceptional cohort represented a once in a lifetime opportunity which, contrary to the prelate's expectation, was not often renewed once the famine was over. Following the war of $1871,{ }^{23}$ Republican leaders distanced themselves from the Churchmen

\footnotetext{
$20 \quad$ AGMAfr Papiers Lavigerie B7 251.

21 AGMAfr B7 168 \& Extrait du procès verbal de la séance du 22 avril 1874.

22 See Michael Barnett, ed., Paternalism Beyond Borders (Cambridge: Cambridge University Press, 2017).

23 Colonel Robin, L'Insurrection de la Grande Kabylie en 1871 (Paris: Charles Lavauzelle, 1900).
} 
and blamed the Mokrani insurrection on the French military themselves. ${ }^{24}$ The early years of the Third Republic led to a massive dispossession of the Algerian elites, the dismantling of much of traditional society and the beginning of a process of proletarianization that lasted until independence in 1962 but, paradoxically, also a growing fear of the threats that established Muslim organizations might present to the colonial order should their monopoly be threatened. Within settler society, anti-clerical and anti-Semitic passions defined the split between moderate republicans and radicals. ${ }^{25}$ While anti-clericalism was effectively the core belief of many republicans, radicals pushed it to its paroxysmal expression. Anti-Semitism which became a trademark of Algerian politics in the 189 os was largely subservient to the vested interests of politicians opposed to moderate republicans supported by the newly enfranchised North African Jewish community. In many ways the context in which orphans who happened to be Arabs and Christians could not have been more hostile.

At the heart of the debates on Christianity in Algeria was the religious dimension of citizenship. Europeans were primarily, notionally at least, Christian in heritage if not practice. Europeans were "naturalized" as Frenchmen in one move in 1889. Jews of North Africa, Sephardic in practice, had been the object of the paternalist interventions of French Jews ${ }^{26}$ and after much lobbying, the Crémieux decree of October 24, 1870 had naturalized them in block. ${ }^{27}$ In the Algerian context Algerians were French nationals but not citizens. By naturalization one thus refers to the gaining of full rights as citizens and the commensurate loss of any specific religious status-in this instance the right to refer to Mosaic laws. As Kamel Kateb has shown, French ethnic policies developed and defined their subgroups over the first 100 years of

For a Marxist analysis of the events of $1871 \mathrm{cf}$. Mahmoud Bennoune, "Origins of the Algerian Proletaria," Middle East Report 94 (1981): 5, 13.

24 Archives d' Outre $\mathrm{Mer}(\mathrm{AOM}), \mathrm{G} \mathrm{GA}_{2} \mathrm{H}_{73}$ rapport sur l' insurrection de 1871 dans la province d'Alger.

25 Аом F80 1685-1686; P. Birnbaum, 'La France aux Français': Histoire des haines nationalistes (Paris: Le Seuil, 1993), 26o-263; P. Hebey, Alger 1898: La grande vague antijuive (Paris: NIL, 1996); G. Dermenjian, La crise anti-juive oranaise, 1895-1905: L'antisémitisme dans l'Algérie coloniale (Paris: L'Harmattan, 1986).

26 Аом F80 1748, Culte Israélite, ordinance of November 9, 1845 on the consistoire of Algeria; report of Béquet, Rapport au conseil de gouvernement, organisation du culte israélite en Algérie (Algiers, 1858).

27 Kamel Kateb, Européens, "indigènes" et juifs en Algérie, 1830-1962: Représentations et réalités des populations, Cahier 145 (Paris: Institut National D’Etudes Demographiques, 2001), 30-68. Florence Renucci, "Les juifs d' Algérie et la citoyenneté (1870-1902). Les enjeux d' un statut contesté," in Droit et justice en Afrique coloniale: Traditions, productions et réformes (Brussels: Publications de l'Université Saint-Louis de Bruxelles, 2013), 97-115. 
colonisation. ${ }^{28}$ This left the largest group of Arabs and Kabyles who under French law had a theoretical choice between their personal status, under Sharia law, or falling into line with the French civil code. While the latter was supposedly a-religious it was necessarily associated with French Christian and occupier rule. The path to naturalization was in fact more arduous and unpalatable than it seems by simply considering the legislative framework. Few chose to become French fully and in an increasingly racialised society, the holding of identity papers counted for little in daily life.

From this administrative logic it did not follow that conversion to Christianity would necessarily represent an act of naturalization. Yet it is testimony to Lavigerie's remarkable power of persuasion and political lobbying that he nevertheless managed to make that claim and to have the French state recognize the validity of his argument. By fiat rather than reasoned legal arguments, the Orphans of Algeria became French because of their sometimes coerced conversion. ${ }^{29}$ The Catholic church had campaigned for their citizenship—established through group naturalization - in a unique response to the Archbishop standing in the Republic. Of course north African Jews had been naturalized through the Crémieux decree of 1870 , the four townships of Senegal enjoyed specific citizenship rights since $1848,{ }^{30}$ but the naturalization of the orphans of Algeria represented a one-off initiative recognizing sui generis the ability of a religious society to adopt and thus make French an entire category of young Arabs.

The Algerian orphans thus became exceptional colonial subjects. They were Catholic because of their rescuing but they remained Arabs-in Algiers the Church made a concerted effort to ensure that their education would take place in Arabic as well as French-yet they were also French citizens. Lavigerie's broader political aims in setting up a path to French colonial citizenship was not assimilation but separate development under his paternal guidance. He had no desire to see "his" Arabs become ordinary Frenchmen- he particularly feared the bad influence of French working class mores. In his letter of March 30, 1889, his protégé Dr Vital pointed out: "It is true, as your eminence judiciously points out, that Algiers is unfortunately like all the large cities, a source of gangrene and by moving in I am unfortunately exposing myself to

28 Kateb, Européens, "Indigènes" et Juifs en Algérie. Also See Pierre-Jean Luizard, Le choc colonial et l'islam (Paris: La Découverte, 2006).

29 Evidence of coercion is limited but there are letters to the prefect in 1874-1875 denouncing forced conversions. See AGMAfr, B 768 letter from Abdelkader Ben Belkassoum, saint Donat, Constantine, June 11, 1875 .

30 See Mamadou Diouf, "The French Colonial Policy of Assimilation and the Civility of the Originaires of the Four Communes (Senegal): A Nineteenth Century Globalization Project," Development and Change 29, no. 4 (1998): 671-696. 
the contagion". ${ }^{31}$ In his colonial Utopia, Christian Arabs would remain rural and would lead the way for a renewal of Arab civilization - restoring North Africa to its antique past when St Augustine and St Cyprien roamed the earth. For Lavigerie the citizenship of his Algerian orphans followed directly from his own personal involvement but echoed his understanding of the Catholic Church in Algeria: a Church of martyrdom (with the cult of Geronimo) and pioneers (with the church of Augustine). While most as Patricia Lorcin and Alain Mahé have shown played up a range of cultural and racial divides between invaders (Arab) and native (Kabyles) along a familiar settler/pastoralist divide, Lavigerie engaged with the Arab world along religious lines. He had had some experience of Middle Eastern Arab identities and through his earlier work in favour of écoles d'orient, did not perceive Arab Christians to be anything else than a restoration - after the turmoil of Islam — of a civilization. ${ }^{32}$ There was thus a direct comparison to be made with the Maronite Christians of Lebanon who had themselves been the object of a colonial project of their own in Algeria as early as $1848 . .^{33}$

Christian Arabs would not be like the corrupt settlers - they would the new men of a new world - a colonial revival in a Christian Mare Nostrum. It is not insignificant that Lavigerie was particularly fond of antiquities and archaeology. His golden age was one in which North Africans were citizens of the Roman world. His project was transformative and engaged with the mythical revival of Latin colonialism which Bugeaud had promoted at the origins of the Algerian colony-in many ways his was an archaeology of this projectliterally exhuming the remains of Roman and Carthaginian North Africa-but it resembled some of the more naïve forms of colonial settlements. Of course, much like the Kabyle myth, this version of the past entailed an eschatological vision of the future which left the current situation wanting. Orphans grew up to be men and women without the heroic attributes of pioneers the prelate had dreamt for them.

\footnotetext{
31 AGMAfr, B9-78, letter of Dr Vital to Lavigerie, March 30, 1889.

32 Matthew Burrows, "'Mission civilisatrice': French Cultural Policy in the Middle East, 186o1914," The Historical Journal 29, 1 (1986): 109-135.

33 The project of mass colonization by Middle Eastern Christian Arabs was aborted due to the pressure from the Ottoman authorities and French desire to keep a protectorate mandate in Syria. Gérald Arboit, "De l' immigration des maronites en Algérie: Un aspect de la politique française à l'égard des communautés chrétiennes de Syrie entre 1848 et 1870," Revue française d'histoire d'outre-mer 87, no. 328-329 (2000): 231-239.
} 


\section{$2 \quad$ Algerian Orphans and the Development of a Colonial Project}

Compared with many people of a similar socio-economic level in the colony, we have much more complete information on the Algerian Orphans of Lavigerie. In particular we have access to a range of private files which give us a brief and incomplete notion of the continued relationship between orphans and church. Much of the correspondence refers to spiritual guidance but it is frequently interspaced with financial demands and narratives of failure to get a sense of the long-term obligations that had been incurred in rescuing children. The Church provided the orphans until the end of their education which varied from primary school and apprenticeship to medical education or seminaries. The children then received a settlement which was intended to set them up for whatever life their education had destined them for.

The choice of education was itself a product of a selection based on aptitude to learn in the specific environment of the orphanages in Algeria and France where the children were brought up. Most were sent to France and lived in a number of institutions pre-existing the crisis. ${ }^{34}$ By 1874 only 239 remained in schools as Children over the age of sixteen were taken off the registers and often served as paid domestic servants at the religious institutions were they had been raised. The religious education favoured the more malleable and younger orphans but even the less academically gifted were encouraged to take on a trade and trained accordingly. As they grew up the Church sought to provide spiritual guidance that would last a lifetime but it also accepted its material responsibilities. In this role the Church was initially supported by the Republican regime of the earlier phase of the Third Republic. ${ }^{35}$

In many ways the missionaries were engaging with the most literal form of paternalism: girls were given a dowry, boys a lump sum on coming of age and on marrying. Four of the most gifted children were trained at some speed for a medical degree with the intention to return them to missionary medical tasks in Algeria. Ultimately this failed to materialize and three out of four did not return. ${ }^{36}$ Yet all of them were provided with the means and credits assurances which enabled them to purchase a practice. While the Church attempted to steer the orphans away from urban centres where temptations might deviate

34 AGMAfr, Papiers Lavigerie B7 40-48, lists for $1872-1873$.

35 AGMAfr Papiers Lavigerie B2 247.

36 AGMAfr Papiers Lavigerie, B9 69. One went to Jaffa and married a Miss Garnier; the second, Michel, married an officer's daughter named Irma Dumarché; another, called Mohammed, married in Gorron (Mayenne); only Vital settled in Algeria but in Algiers rather than the villages. 
them from the holier life they had been prepared for, many flocked to the urban centres to join in the new proletariat.

Whatever their fate the Church remained the main provider of patronage, credit and identity. When a servant wished to marry she had to resort to the Church. The Algerian clergy found itself in the position of providing evidence of civil identity in the shape of the Actes de notoriété. ${ }^{37}$ Some twenty years later, some like Berthe Louisant, a domestic servant in Grenoble-by then utterly naturalised and Christianized - sought to obtain a "document that could constitute somewhat my identity" in order for her to marry. ${ }^{38}$ This long term connection was sometimes maintained explicitly at the request of the orphans themselves, over the decades that followed 1868.

At the same time as when the administration attempted to resettle Alsatians and Lorrains fleeing German occupation, with limited results and means - the Catholic Church purchased land and rights. Acting like many large colonial businesses beforehand the Church acquired enough arable land for two village developments which were set in a commune mixte (a commune where the Arab population dominated demographically). Under the names of Ste Monique and St Cyprien (North African saints) the two little villages were set up as distinct entities but within close proximity from one another. St Cyprien was a saint name that had already been employed in Algeria when the first bishop of Algiers, Dupuch, founded his own small orphanage in 1839. ${ }^{39}$ The funding for the foundation of the villages combined French national assembly funding and Algerian funds. Between 1871 and 1877 the new Third Republic proved a very ambiguous regime and one in which the Catholic clergy could exercise a significant amount of influence. ${ }^{40}$ While Lavigerie manipulated local and national politicians into supporting his works, he also set up his organizations as societies - avoiding thus the debates on congregation politics. The villages were thus set up as belonging to a private society entrusted with the paternalist authority of the archbishop. The two villages were relatively plain in design (and in this sense did not echo the more grandiose Utopian urbanism of many paternalist enterprises of the 19th century) and only the large churches signalled them out as prestige ventures. As a colonial project, the plans were simple: a commercial society created in 1873 was endowed with land by Lavigerie. Each couple of colonists was attributed a house of 10 by 5 meters, 20

37 The registration of Algerian état civil was imposed by the law of February 23, 1882.

38 AGMAfr, Papiers Lavigerie, B7 110.

39 Abbé Monterat, Mémoire en faveur de Mgr Dupuch premier et ancien évêque d'Alger à l'appui de la manifestation du clergé d'Afrique (Algiers: n.p., 1852).

40 AGMAfr, Papiers Lavigerie, B2-247. 
hectares of land, 12 of which arable and 8 grazing, furniture, a plough, seeds and food for a year at a cost of 4,00o francs per household while the animals were offered as an interest free loan over ten years. ${ }^{41}$ Thanks to lobbying in the French parliament a second village was subsidized to the tune of 75,000 francs in 1875 .

Located close to the railways and in the midst of a plain overlooked by tribal territories, they could access colonial markets and the Algerian hinterland. As some of the orphans originating from these tribal groups they could maintain some family bonds while demonstrating, it was expected, the superiority of French farming and culture. Nuns would staff the dispensary and priest would provide primary education. Two churches were built. Each house would be simple but designed for the couples matched by the Catholic church. Ideally children would thus marry within the community and resist the lure of large cities. Reality failed to match the aspirations of course. Girls married for love or to escape the community, boys left to chance their fortune away from their villages. Incomers also mingled with the community and muddled somewhat the purity of the model villages. ${ }^{42}$ The Church turned into matrimonial agency set up couples (many of whom turned out to be quite dysfunctional), it also set up the Catholic schools and provided machinery and facilities. It also lent its name to the enterprise and gave credit worthiness to the new colonists. The Catholic dispensary was intended to be a window on the benefits of modernity - in this sense the Catholic church pre-empted many of the reforms of medical missionary work in the Catholic Church. In its location and aims the villages were meant to turn into beacons for conversion. It was hoped that tribesmen would spontaneously associate Catholic faith and modernity and, confusing correlation and causation, might convert. It became obvious to all that this model of conversion through development was illusory.

The history of the villages was marked by a series of tragic incidents, such as the murder of a priest in 1880 or an attack on its dispensary. ${ }^{43}$ Attacks on the medical structure and the general reluctance to attend most of its provisions reflected an active rejection of colonial medicine and not only the discerning

41 AGMAfr, B7-310 [1], Conseil supérieur de gouvernement, $3^{\mathrm{e}}$ commission, budget de 1876, subvention pour l'établissement des indigènes naturalisés français, élevés dans les orphelinats, 5 .

42 For instance Jeanne, daughter of Geronimo, married Augeix in 1892, a Frenchman from Royat-les-Bains working for the French railways, in spite of her father's desire that she should only marry a Christian Arab from Les Attafs. See AGMAfr Papiers Lavigerie, B9 448-454.

AGMAfr Papiers Lavigerie, B10 2. In February 188o. 
choice that was identified by Yvonne Turin. ${ }^{44}$ Beyond the difficulties of meeting the needs of its community and the cost of resourcing services for the Arab tribes, the villagers were always on the brink of economic survival themselves. At several times, the villagers had to call on the Church to bail them out. In 1892 their survival was in question when the crops failed across the entire North African colony.

For churchmen one of the main preoccupations was the risk of relapsing into Islam-either because of disillusionment with the harsh theocratic rule of village life which barred dissent and deviance or because meeting a mate within such a small community proved difficult. Being French nothing could stop the villagers from settling anywhere in France or Algeria and disappear. This anxiety kept the clergymen awake but it soon became a central aspect of the campaigns that were launched against the villages.

French Algerian politics in the 1870 os and 188 os took a decidedly anticlerical flavour with specific features studied by Saaïdia. ${ }^{45}$ The "opportunist" republicans ruled Algeria and their opponents, the Radicals, soon challenged the racial underpinning of this rule. Anticlericalism took a violent and visceral dimension. Algerians deputies targeted the villages as an anomaly, once sponsored by the public purse but also as one that challenged the social and religious norms of the colony. They denounced them as economic failures kept alive through unfair subsidies. They challenged the religious identity of the villagers and accused them of being Muslim in disguise-implicitly renouncing their French citizenship. Finally they lobbied that the villages should be drowned in larger entities where their identity would soon disappear. Despite their actual citizenship the administrators consistently attempted to challenge their religious identity or the relevance of religion to national identity. In every possible way that sought to place back the converts among the natives and deny them electoral rights. ${ }^{46}$ Journalists in the Republican press predicted that their fate would be an unviable one:

Everybody knows the repulsion Arabs have towards Jews, well it is even worse for Christian Arabs. So Mgr should not hide that should an insurrection occur, the first victims would certainly be his creatures. Let us hope

44 Yvonne Turin, Affrontements culturels dans l'Algére Coloniale: Écoles, Médecines, Religion, 1930-1880 (Paris: Maspero, 1971).

45 Oissila Saaïdia, 'L' anticléricalisme article d' exportation: Le cas de l' Algérie avant la première guerre mondiale," Vingtième Siècle: Revue d'histoire 87, no. 3 (2005): 101-112.

46 J. Tiquet, Une expérience de petite colonisation indigène en Algérie: Les colons arabes-chrétiens du Cardinal Lavigerie (Algiers: Maison Carrée, 1936), 93. 
for our own safety that the government of Algeria will prevent the setting of another centre composed exclusively of Christian arabs.

Reporting on the failure of the village, by then a few months old, the journalist then proceeded to report that their neighbours called them "the archbishop's slaves" 47 This reflected the fact that these villages were uniquely disruptive of the colonial order. After the group naturalization of 1874 the two villages became the only examples of universal suffrage returning entirely Arabic municipal councils in Algeria.

This disturbance endured and was regularly denounced as a subversion of colonial rule but also as a challenge to the rule of law and the defence of human rights. Somewhat disingenuously radicals intended to save the Christian Arabs from living their lives under the yoke of clericalism. In practice a constant campaign begun in 1874 sought to make the villages vanish as identifiable entities. By 1892 radicals got their way and the villages were absorbed into a larger village of colonization, created by decree in 1878 and renamed Wattignies in 1889 . Nevertheless the converts' very Catholic demography enabled them to grow to such an extent that it was them who took over the larger commune. ${ }^{48}$ Over two generations the growth of a Catholic and Arabic polity in the midst of a radical-socialist one challenged Algerian norms in more ways than one. Being Catholic was a first red flag to which, increasingly, being Arab was associated. Radicals accused the society of financial improprieties, of abuse of power and clerical interference in the life of the villagers and even the somewhat disingenuous championing of the civic rights of those who broke the theocratic rules. As a community these villages were set up very strictly and the society's churchmen led the parishes in strict paternalistic fashion. A drunk or a wife beater might get expelled as might a less religiously minded member of the community. Accused of keeping themselves to themselves, despite evidence of rapid interracial marriages, these villagers challenged their increasingly racialized notions of identity. The establishment of these communities in particular challenged the code de l'indigénat which codified in 1874 the regime of segregated inequality between colonists and ethnic groups of Algeria. ${ }^{49}$

Under this constant barrage of criticism, the Catholic Church started to doubt the validity of the claims that had been made for the villages. Unlike

47 AGMA fr, B7-302, Felix Devalier, Algérie, August 21, 1874.

48 АОМ 1 Y 110.

49 For an analysis of some of the medical grounding of racial theories in Algeria see Patricia M.E. Lorcin, "Imperialism, Colonial Identity, and Race in Algeria, 1830-1870: The Role of the French Medical Corps," Isis 9o, no. 4 (1999): 653-679; Olivier Le Cour Grandmaison, De l'indigénat. Anatomie d'un "monstre" juridique: Le droit colonial en Algérie et dans l'empire français (Paris: Zones/La Découverte, 2010), chapter 2. 
model factories or farms, the villages had not retained their experimental purity and, beyond its main critiques, it did not attract as much positive or supportive attention as had been anticipated. As père Tiquet writing in the $1930 \mathrm{O}$ chronicled the life of the villages, he reported on the stories of village tensions and noted that there were not many significant differences between the Arab villagers and other colonists of the commune when it came to their deportment and morality.

After a hiatus of some twenty years the villages came back to the attention of the metropolitan state in 1902. At the peak of the debates on the separation of Church and State, the fiercely anticlerical Combes' ministry responded to local pressure to investigate how a small village could be controlled by clerically minded Arabs. ${ }^{50}$ The response investigated how gerrymandering might enable radicals to dominate but only to admit that it had already done so in the past to no effect:

It is not within the reach of the administration to put down this clerical centre since we are facing citizens exercising their rights legally and according to our legislation ... as to modifying the sections in order to favour the Frenchmen of European origins, our administration has done what it could at this stage. The political importance of this situation is minimal. The case of a village of Arabs educated by Catholic priests is unique in Algeria and there is no reason to believe it will occur again. ${ }^{51}$

At the same time Radicals promoted as a victim of clerical violence a local drunkard Philippe Djelloul, who had been expelled from St Cyprien. Under public opinion pressure and the sustained campaigning of the left wing press, the oeuvre des orphelinats disposed of its assets and ceased trading in 1904. Setting the villages free the society gave to Christian Arabs full ownership of their villages while removing itself from governing them. Despite this removal, villagers remained under scrutiny. For the leadership of the villages, there could be no peace in the "Clochemerle" world they inhabited. Their local politician Frachebois was at once a dangerous radical for the White Fathers and a rabid clericalist for the Radicals who hated what he stood for. Frachebois was under close scrutiny from the French prefecture in particular for his supposed favouring of native and clerical interests over newly settled Europeans. ${ }^{52}$ Arab converts could not satisfy either Christian idealism or Radical anticlericalism.

\footnotetext{
5 о $\quad$ AOM F/8o/1693.

51 АОм F/8०/1693, rapport du préfet, 20/12/1902.

52 AGMAfr B9 435 each supporter of Frachebois was accused of betrayal by the White Fathers.
} 
This inability to belong to the colonial order is one witnessed in the files of individuals working in the colony. Some acting as translators or teachers, such as Célestin Salem, intituteur at the Commune mixte de Fort National would come under similarly untenable pressures. The Commune accused Salem of being clerically minded in being unwilling to teach his Muslim pupils on Sunday. ${ }^{53}$ Despite his heroic resistance to the authorities on a point of principle, Churchmen found fault in his writings and in his school which seemed to them too secular. ${ }^{54}$ When he applied for his children to received private Catholic education, the clergy refused on the ground that he was still employed in a secular school system. Acutely aware of the fact that the White Fathers had now prioritized sub-Saharan Africa, he protested that racial discrimination was now in place in the missionary world and that "African negroes" rather than white children were now catered for. This assimilation to whiteness when, some might argue the colonial world emphasized the non-whiteness of Algerians, signifies the difficulty of standing on the threshold of a racialized colonial society. ${ }^{55} \mathrm{In}$ his own setting, Salem prided himself on baptizing his own entire family and 14 orphans in articulo mortis.

In civil law Christian Arabs faced the complexities of straddling two separate legal systems and of having different rules on most things than their own closest relatives. Sharia law might apply to part of their family as might the laws regulating property while they could no longer call on this specific jurisdiction. The French legal regime in Algeria created endless zones of friction and community boundaries.

Their hybridity had been the purpose of setting them up as alternative colonial villages but this Creole identity relied on being able to maintain some kind of equilibrium between two cultural and economic contexts. Like the more autonomous orphans around France and Algeria, they had been forcibly alienated from mainstream Algerian culture. They spoke and wrote Arabic but they had learnt it through readings of the New Testament rather than Muslim sacred texts. As a community there were too few of them to preserve the endogamy that alone would have preserved the validity of the experiment. Ironically Catholic policies ended up seeking a kind of racial purity they berated in their political adversaries. Yet the reality soon caught up as Arab widows married Europeans. Even within the first generation mixed marriages outnumbered

53 On instituteurs see Fanny Colonna, Instituteurs Algériens, 1883-1939 (Paris: Sciences Pos, 1975).

54 AGMAfr, PL, B9 237-243.

55 AGMAfr, PL, B9 248, 16.01.1891. 
endogamous ones. ${ }^{56}$ While their detractors reified their Arab nature it seems that the village dwellers became examples of colonial assimilation into the Mediterranean melting pot of European settlers. Furthermore the villages were drained by the appeal of large multicultural colonial cities. St Cyprien declined from 38 o inhabitants in 1909 to 16 o in 1921, following thus the general pattern of Algerian rural exodus.

The missionary developmental project survived its initial aims but failed its grander aspirations - in contrast the villages set up around missions in subSaharan Africa seemed to have been much more popular and successful, what were the causes of this mediocre success? The first point is clearly the lack of clarity of these settlements in relation to colonial ones. Set up as businesses in order to resist the political pressures on religious congregations, the villages were economically dependent for much of their initial existence. They were not colonial projects aligned with the settlers' own free trading agenda benefiting as they did from endowments and subsidies. Economically dependent they also challenged the political status quo around the personal status of Arab subjects. ${ }^{57}$ They were full of citizens whose citizenship and French identity it was claimed rested on their religion and their Arab origins - in contrast to the naturalization of Europeans of various origins whose assimilation in the French polity was based neither on nativism nor culture or religion but rather on some vague racial assimilation: they had become French because they were not Arabs. Though a small and vulnerable group, the Arab converts presented a robust and disturbing challenge to the settlers-while they also challenged the fallacy of the personal status of Muslim subjects. In a society increasingly resting on the proletarianization of the Arab people and their political marginalization, they presented a challenge that could not be ignored even if it was a kind of evolutionary political and governmental dead end. Paradoxically they also challenged — as was intended - traditional society and it is this challenge to society that remains today for the handful of Christian converts still living in Algeria. ${ }^{58}$

$5^{6} \quad$ Tiquet, Une Expérience, 126.

57 On the complexities see "Des Effets Juridiques du Changement de Religion en Algerie," J. Dr. Int'l Prive \& Juris. Comparée 375 (1908).

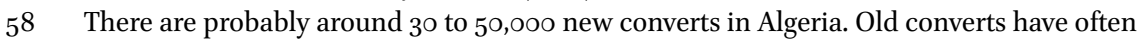
left Algeria with the French and are now almost invisible. Karima Dirèche, "Évangélisation en Algérie: débats sur la liberté de culte," L'Année du Maghreb 5 (2009): 275-284, available via http://journals.openedition.org/anneemaghreb/596; DoI: 10.400o/anneema ghreb.596. 
The material conditions of the mission - to borrow from Jean Pirotte's concept-became the more preoccupying aspect of its existence.$^{59}$ The theocratic model failed in a secularist environment, it was economically mediocre and socially ordinary. As an ideal of developmentalism it failed to live up to the high aspirations its promoters had. Algeria closed up again to proselytizing not because of the military concerns that had been so restrictive before 1870 but because religious conversion threatened the established order of a profoundly segregated society. The hybridity that convert citizens represented challenged all forms of social and political structuring in place or in the making in Algeria. Like many of Lavigerie's grand schemes the mundane details of the programme did not live up to the prospectus claims. The humanitarian funding at the onset had been a one off which became difficult to sustain over the long term - the conversion of the Arabs remained an unfulfilled aspiration and the archaeology of the church of St Augustine only populated the museums.

\section{Bibliography}

Archives des Missionnaires d'Afrique (AGMAfr). Papiers Lavigerie.

Archives Nationale d' Outre Mer. Fonds des départements d' Alger, Constantine et Oran. La misère d'Algérie.

Arboit, Gérald. "De l'immigration des maronites en Algérie: Un aspect de la politique française à l'égard des communautés chrétiennes de Syrie entre 1848 et 1870." Revue française d'histoire d'outre-mer 87, no. 328-329 (2000): 231-239.

Aldrich, Robert. The French Presence in the South Pacific, 1842-1940. London: Macmillan, 1990.

Barthès, Henri. Monseigneur de las Cases, évêque de Constantine. Montpellier: Presses Universitaires de Paul Valéry, 1980.

Barnett, Michael ed. Paternalism Beyond Borders. Cambridge: Cambridge University Press, 2017.

Bellarmin-Vincent Burzet, Abbé. Histoire des désastres de l'Algérie, 1866-1867-1868: Sauterelles, tremblement de terre, choléra, famine. Algiers: Garaudel, 1869.

Bennoune, Mahfoud. "Origins of the Algerian Proletariat." Middle East Report 94 (1981). Benoist, Joseph-Roger de. Église et Pouvoir Colonial au Soudan Français. Paris: Karthala, 1987.

Birnbaum, Pierre. 'La France aux Français': Histoire des haines nationalistes. Paris: Le Seuil, 1993 .

59 Jean Pirotte ed., Les Conditions Matérielles de la Mission (Paris: Karthala, 2004). 
Burrows, Matthew. “'Mission civilisatrice': French Cultural Policy in the Middle East, 186o-1914." The Historical Journal 29, 1 (1986): 109-135.

Ceillier, Jean-Claude. Histoire des missionnaires d'Afrique (Pères Blancs), de la fondation par Mgr Lavigerie à la mort du fondateur (1868-1892). Paris: Karthala, 2008.

Colonna, Fanny. Instituteurs Algériens, 1883-1939. Paris: Sciences Pos, 1975.

Curtis, Sarah E. Civilizing Habits: Women Missionaries and the Revival of French Empire. Oxford: Oxford University Press, 2010.

Daughton, James-Patrick. An Empire Divided: Religion, Republicanism and the Making of French Colonialism, 1880-1914. Oxford: Oxford University Press, 2006.

Daughton, James-Patrick and Owen White. In God's Empire: French Missionaries and the Modern World. Oxford: Oxford University Press, 2011.

Denéchère, Yves. "Histoires croisées des orphelins et de l' adoption." In Invisibles orphelins, edited by Magali Molinié. Paris: Autrement, 2011.

Dermenjian, G. La crise anti-juive oranaise, 1895-1905: L'antisémitisme dans l'Algérie colonial. Paris: L'Harmattan, 1986.

“Des Effets Juridiques du Changement de Religion en Algerie." J. Dr. Int'l Prive \& Juris. Comparée 375 (1908): 375-395, 989-1001.

Diouf, Mamadou. "The French Colonial Policy of Assimilation and the Civility of the Originaires of the Four Communes (Senegal): A Nineteenth Century Globalization Project." Development and Change 29, no. 4 (1998): 671-696.

Dirèche, Karima. Chrétiens de Kabylie (1873-1954): Une action missionnaire dans l'Algérie coloniale. Saint Denis: Bouchène, 2004.

Dirèche, Karima. "Les écoles catholiques dans la Kabylie du XıX siècle." Cahiers de la Méditerranée 75 (2007): 17-27, available via http://journals.openedition.org/cdlm/ 3333.

Dirèche, Karima. "Évangélisation en Algérie: débats sur la liberté de culte." L'Année du Maghreb 5 (2009):275-284, available via http://journals.openedition.org/anneemag hreb/596; Dor: 10.400o/anneemaghreb.596.

Émerit, Marcel. “Le problème de la conversion des musulmans d' Algérie sous le Second Empire: Le conflit entre Mac-Mahon et Lavigerie." Revue Historique vol. 223, no. 1 (1960): 63-84.

Frémeaux, Jacques. Les bureaux arabes dans l'Algérie de la conquête. Paris: Denoël, 1993.

Le Cour Grandmaison, Olivier. De l'indigénat. Anatomie d'un "monstre" juridique: Le droit colonial en Algérie et dans l'empire français. Paris: Zones, 2010.

Hannoum, Abdelmajid. "Colonialism and Knowledge in Algeria: The Archives of the Arab bureau." History and Anthropology 12, no. 4 (2001): 345-379.

Hanoteau, Adolphe, and Aristide Letourneux. La Kabylie et les coutumes Kabyles. Paris: Imprimerie Nationale, $1872-1873$.

Hebey, P. Alger 1898: La grande vague antijuive. Paris: NIL, 1996.

Hugonnet, Léon. La Crise algérienne et la démocratie. Paris: Chevalier, 1868. 
Julien, Charles André. Histoire de l'Algérie Contemporaine, vol. 1. Paris: Presses Universitaires de France, 1986.

Kateb, Kamel. Européens, “indigènes” etjuifs en Algérie, 1830-1962, représentations et réalités des populations. Paris: Presses Universitaires de France, 2001.

Lester, Alan, and Fae Dussart. Colonization and the Origins of Humanitarian Governance: Protecting Aborigines across the Nineteenth-Century British Empire. Cambridge: Cambridge University Press, 2014.

Lorcin, Patricia M.E. Kabyles, arabes, français: Identités colonials. Limoges: Presses Universitaires de Limoges, 2005 .

Lorcin, Patricia M.E. "Imperialism, Colonial Identity, and Race in Algeria, 1830-1870: The Role of the French Medical Corps." Isis 9o, no. 4 (1999): 653-679.

Luizard, Pierre-Jean. Le choc colonial et l'islam. Paris: La Découverte, 2006.

Mahé, Alain. Histoire de la Grande Kabylie, anthropologie historique du lien social dans les communautés villageoises. Saint Denis: Bouchène, 2001.

Montclos, Xavier de. Lavigerie le Saint-Siège et l'Église: De l'avènement de Pie IX à l'avènement de Léon XIII, 1846-1878. Paris: de Boccard, 1965.

Monterat, Abbé. Mémoire en faveur de Mgr Dupuch premier et ancien évêque d'Alger à l'appui de la manifestation du clergé d'Afrique. Algiers: n.p., $185^{2}$.

Pirotte, Jean, ed. Les Conditions Matérielles de la Mission. Paris: Karthala, 2004.

Renault, François. Le Cardinal Lavigerie. Paris: Fayard, 1992.

Renucci, Florence. "Les Juifs d'Algérie et la citoyenneté (1870-1902): Les enjeux d'un statut contesté." In Droit et justice en Afrique coloniale: Traditions, productions et réformes, 97-115. Brussels: Publications de l'Université Saint-Louis de Bruxelles, 2013.

Rey-Goldzeiguer, Annie. Le Royaume arabe, la politique algérienne de Napoléon III. Algiers: Société Nationale d'Édition et de Diffusion, 1977.

Robin, Colonel. L'Insurrection de la Grande Kabylie en 1871. Paris: Charles Lavauzelle, 1900.

Saaïdia, Oissila. Algérie coloniale. Musulmans et chrétiens: Le contrôle de l'Etat (18301914). Paris: CNRS, 2015.

Saaïdia, Oissila. "L'anticléricalisme article d'exportation: Le cas de l'Algérie avant la première guerre mondiale." Vingtième Siècle: Revue d'histoire 87, no. 3 (2005): 101112.

Sari, Djilali. Le désastre démographique. Algiers: Société Nouvelle d'Édition et de Diffusion, 1982.

Spillmann, Georges. Napoléon III et le royaume arabe d'Algérie, Travaux et mémoires de l'Académie des sciences d' outre-mer, nouvelle série 3. Paris: Académie des Sciences d' Outre-mer, 1975.

Taithe, Bertrand. "Missionary Militarism? The Armed Brothers of the Sahara and Leopold Joubert in the Congo." In God's Empire: French Missionaries and the Modern 
World, edited by James-Patrick Daughton and Owen White, 129-150. Oxford: Oxford University Press, 2011.

Taithe, Bertrand. "Algerian Orphans and Colonial Christianity in Algeria 1866-1939." French History 20, no. 3 (2006): 240-259.

Tiquet, J. Une expérience de petite colonisation indigène en Algérie: Les colons arabeschrétiens du Cardinal Lavigerie. Algiers: Maison Carrée, 1936.

Turin, Yvonne. Affrontements culturels dans l'Algére Coloniale: Écoles, Médecines, Religion, 1930-1880. Paris: Maspero, 1971.

Urvoy, Dominique. "Les conversions au catholicisme en Algérie." Outre-Terre 4, no. 45 (2015): 249-255.

Zom, Jean-François. Le Grand Siècle d'une mission protestante: La mission de Paris de 1822 à 1914. 2nd ed. Paris: Karthala, 2012. 